\title{
Variation in Lysis of Walls of Sclerotinia fructigena with Age of Culture
}

\author{
By FUENSANTA REYES AND R. LAHOZ \\ Instituto 'Jaime Ferrán' de Microbiología del Consejo Superior de \\ Investigaciones Cientificas, Joaquin Costa 32, Madrid-6, Spain
}

(Received 27 September 1976)

\section{INTRODUCTION}

Lysis of walls of filamentous fungi by micro-organisms or by enzymes obtained from micro-organisms has been studied in a number of fungi (Skujins, Potgieter \& Alexander, I965; Jones et al., 1968). Lysis of a fungus can also occur through autolysis involving its own lytic enzymes which may be located on the wall (Mitchell \& Sabar, 1966; Polacheck \& Rosenberger, 1975) or excreted into the medium during the autolytic phase of growth (Ko \& Lockwood, I970; Reyes \& Byrde, I973). These lytic enzymes are considered to play an important role in cell growth and in both ecological and pathogenic processes.

In the present communication we describe the lysis of walls of the fungus Sclerotinia fructigena of different ages by endogenous lytic enzymes and by preparations of lytic enzymes produced during autolysis of the fungus.

\section{METHODS}

Organism. Sclerotinia fructigena (ATCC24976) was obtained from Dr R. J. W. Byrde (Bristol). Conidia were obtained by the method of Byrde \& Fielding (I968).

Medium and culture conditions. Sclerotinia fructigena was grown on a mineral medium supplemented with Difco yeast extract ( $\mathrm{g} \mathrm{l}^{-1}$ ) as described by Reyes \& Byrde (I973). Samples were taken periodically to determine the degree of autolysis, the excretion of lytic enzymes into the culture fluid and to obtain wall preparations of different ages. The degree of autolysis was defined as the percentage loss in mycelium dry weight between the day of maximum growth (taken as the starting point of autolysis) and the day on which the sample was taken. Autolysis was considered to have ended on the day from which the degree of autolysis was constant.

Culture filtrates. These were adjusted to their original volume with distilled water and assayed for $\beta$-N-acetylglucosaminidase (EC. 3.2.I.30), chitinase (EC. 3.2.I.I4) and I,3- $\beta$-glucanase (EC. 3.2. I.6) activities.

Production of autolytic enzymes. Lytic enzymes were precipitated from the culture filtrates of 80- to 90-day autolysed cultures using the tannic acid method of Shibata \& Nisizawa (1965). The dried precipitate was stored at $4{ }^{\circ} \mathrm{C}$ and the lytic enzyme activities, which were stable for at least 6 months, were tested periodically.

Wall preparations. These were obtained by freezing the mycelium at $-20{ }^{\circ} \mathrm{C}$, grinding with a pestle and mortar and breaking in an ultrasonic disintegrator (MSE model MK2, $150 \mathrm{~W}$ ).

Determination of enzyme activities in walls in situ. Walls from cultures of different ages were suspended at $0 . \mathrm{I} \% \mathrm{w} / \mathrm{v})$ in $0.05 \mathrm{M}$-borate/citrate/phosphate buffer, $\mathrm{pH} 5.5$, and the suspensions were assayed for $\beta$ - $N$-acetylglucosaminidase, I,3- $\beta$-glucanase, acid phosphatase (EC. 3.I.3.2) and invertase (EC. 3.2.I.26). After stopping the enzymic reactions (see 
below), the walls were separated by centrifuging and the substrate transformed was assayed in the supernatants.

Wall degradation. This was measured by the method of Hughes (197I), adapted by Reyes \& Byrde (1973).

Chemical assays. Free glucose in the enzymic hydrolysates of $S$. fructigena walls from cultures of different ages was estimated with glucose oxidase (De la Fuente $\&$ Sols, personal communication). $\mathrm{N}$-Acetylglucosamine and glucosamine were determined as described by Tracey (1955).

Enzyme assays. $\beta$ - $N$-Acetylglucosaminidase, I,3- $\beta$-glucanase and acid phosphatase activities were assayed as described by Reyes \& Byrde (1973). Invertase was assayed by the hydrolysis of sucrose. The reaction was stopped by adding Somogyi reagent and the glucose liberated was determined by the methods of Somogyi (1945) and Nelson (I944). Chitinase was determined using a colloidal chitin suspension from prawn shell chitin prepared by the method of Jeuniaux (I966).

\section{RESULTS}

\section{Phases of growth and production of 1,3- $\beta$-glucanase}

The degree of autolysis in $S$. fructigena was $70 \%$ after 98 days growth ( 77 days of autolysis). I,3- $\beta$-Glucanase activity was always found in the culture filtrate once autolysis had begun, and its accumulation was related to the degree of autolysis. After 98 days growth, the I,3- $\beta$-glucanase activity was 6.2 units/flask, i.e. a specific activity of 0.48 units (mg protein $)^{-1}$ in the culture fluid. In extracts of mycelium the enzyme was detected before autolysis began ( 0.04 units/flask after I4 days growth) and its activity increased to a constant value ( $\mathrm{I} \cdot \mathrm{O}$ units/flask) during autolysis, decreasing again to 0.2 units/flask at the end of autolysis.

\section{Wall degradation}

Preliminary experiments were carried out with walls obtained from a I5-day culture. The degree of lysis after $44 \mathrm{~h}$ in buffer at $\mathrm{pH} 5.5$ was $40 \%$ in $0.05 \mathrm{M}$-borate/citrate/phosphate buffer, $30 \%$ in $0.05 \mathrm{M}$-acetate buffer, $35 \%$ in $0.066 \mathrm{M}$-phosphate buffer, and $24 \%$ without buffer. Various borate/citrate/phosphate buffer concentrations from 0.05 to $0.5 \mathrm{M}$ all gave a value of $40 \%$ lysis after $24 \mathrm{~h}$ incubation. The choice of $\mathrm{pH} 5.5$ was based on an earlier finding (Reyes \& Byrde, I973). Breakage and division of the walls influenced the extent of lysis. Samples (I mg dry wall per $\mathrm{ml}$ water) were broken at $4{ }^{\circ} \mathrm{C}$ either with a pestle and mortar (10 min), or by magnetic stirring ( $30 \mathrm{~min}$ ), or by various periods (I to ro min) of ultrasonic disintegration. The degree of lysis of these samples after $\mathrm{I} 22 \mathrm{~h}$ incubation with the lytic enzymes varied from $3 \mathrm{I} \cdot 3$ to $52 \%$, but was constant at $52 \%$ for all samples subjected to ultrasonic disintegration for $4 \mathrm{~min}$ or more. The degree of lysis in samples containing from 0.25 to $\mathrm{I} .5 \mathrm{mg}$ dry wall was the same in all samples after $24 \mathrm{~h}$ incubation.

Lytic enzymes found in autolysed culture filtrates of $S$. fructigena were also present in wall preparations from this fungus. The concentrations of the four lytic enzymes studied increased with age to a maximum from mycelium which was $40 \%$ autolysed, but rapidly decreased on subsequent aging.

Figure I shows the gradual decrease in the degree of lysis after $240 \mathrm{~h}$ incubation of $S$. fructigena walls from cultures of different ages. Lysis decreased from $45 \%$ in walls from I5-day cultures to $10.5 \%$ in walls from 77 -day cultures; this degradation occurred to a lesser extent ( $8 \%$ to $2 \%$, respectively) in walls incubated without the addition of an exogenous supply of lytic enzymes. 


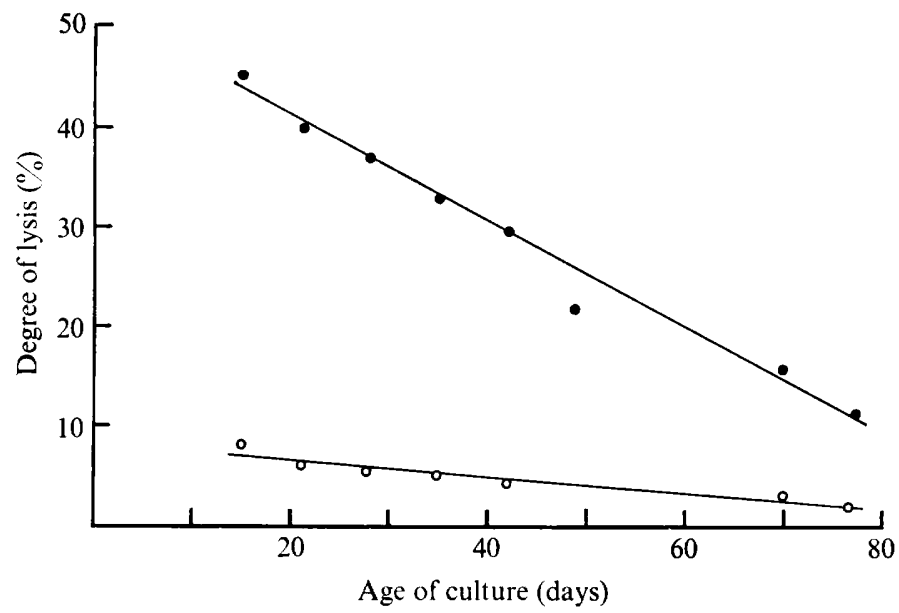

Fig. I. Degree of lysis (\%) after $240 \mathrm{~h}$ incubation of walls of Sclerotinia fructigena from cultures of different ages with (O) an exogenous supply of lytic enzymes, $(\bigcirc)$ endogenous enzymes only.

The rate of wall lysis was greatest in the first hour; after $24 \mathrm{~h}$, lysis increased only slowly with time. The lytic enzymes did not lose their activities during incubation with the walls. Wall lysis did not occur with enzyme preparations that lacked $1,3-\beta$-glucanase activity. The amount of glucose liberated decreased with increasing age of the cultures from which the walls were obtained, varying from $\mathrm{I} \cdot 23$ to $0.86 \mu \mathrm{mol}(\mathrm{mg} \text { wall })^{-1}$ in walls from $\mathrm{I} 2-$ to 82-day cultures. Smaller amounts of free $\mathrm{N}$-acetylglucosamine and glucosamine were detected: the concentrations found in samples of different ages were similar and never more than $0.05 \mu \mathrm{mol}(\mathrm{mg} \text { wall })^{-1}$. Chitinase activity was detected only in small quantities in enzyme precipitates from autolysed cultures.

\section{DISCUSSION}

The fungus $S$. fructigena cultured in these conditions was $70 \%$ autolysed after incubation for 70 to 100 days. This high degree of autolysis can be obtained only when degradation of the cytoplasm and walls occurs.

$\mathrm{I}, 3-\beta$-Glucanase activity was always present in the culture medium after autolysis had begun, but it was also found in mycelial extracts and in walls from samples in the exponential and stationary phases of growth. The presence of I,3- $\beta$-glucanase and other lytic enzyme activities in extracts of mycelium and in walls of $S$. fructigena before autolysis began confirms that there is a balance between synthesis and lysis of the wall polymers during growth (Bartnicki-García \& Lippman, 1972) but the equilibrium can be displaced towards wall degradation (beginning of autolysis) when synthesis stops due to lack of nutrients. The excretion and accumulation of lytic enzymes in the medium during the autolytic phase of growth can be considered a consequence of this process.

In the enzymic hydrolysate of $S$. fructigena walls, the production of glucose was greater than that of $N$-acetylglucosamine, in agreement with the finding of Mahadevan \& Rao (1970) who studied the enzymic degradation of conidial walls during germination of Neurospora crassa.

In the walls of Sclerotinia fructigena, $\beta$ - $N$-acetylglucosaminidase, acid phosphatase, invertase and I,3- $\beta$-glucanase were all determined in situ. Lytic enzymes have also been characterized in Pythium butleri and Pythium myriotylum (Mitchell \& Sabar, I966), Neuro- 
spora crassa (Mahadevan \& Mahadkar, 1970) and Aspergillus nidulans (Polacheck \& Rosenberger, 1975).

The different concentrations of lytic enzymes found in the mycelial extracts, walls and culture fluid suggest that during autolysis lytic enzymes accumulate in the walls causing degradation of structural polymers, and subsequent liberation of lytic enzymes into the culture fluid. The constant level of lytic enzymes in the mycelial extract over a long period during autolysis could be explained as a dynamic equilibrium between the amounts of lytic enzymes formed and excreted. When the autolytic process reaches a certain point there is a disorganization of the mycelium and the equilibrium is displaced towards excretion and autodestruction, with a limit being reached at the completion of autolysis. The relatively high values for the degree of wall lysis when exogenous lytic enzymes were present suggest that the degradable fraction had been exhaustively attacked. A longer period would be needed to degrade walls to a comparable extent with the endogenous enzymes. Even so, this degree of lysis could never be attained, since location of the enzyme on the walls would make the vulnerable area inaccessible to complete degradation by the enzyme.

The differing degrees of lysis found in walls from young and old cultures could be due to the disappearance during the autolytic phase of growth of the fraction of the wall most susceptible to digestion.

We thank Dr R. J. W. Byrde for helpful suggestions in this work and for the culture of Sclerotinia fructigena, and we are indebted to Miss Teresa Raposo for technical assistance.

\section{REFERENCES}

BARTNICKI-García, S. \& Lippman, E. (1972). The bursting tendency of hyphal tips of fungi: presumptive evidence for a delicate balance between wall synthesis and wall lysis in apical growth. Journal of General Microbiology 73, 487-500.

Byrde, R. J. W. \& Fielding, A. H. (1968). Pectin methyl-trans-eliminase as the maceration factor of Sclerotinia fructigena and its significance in brown rot of apple. Journal of General Microbiology 52, 287-297.

Hughes, R. C. (197I). Autolysis of Bacillus cereus cell walls and isolation of structural components. Biochemical Journal 121, 79I-802.

JeUniauX, C. (1966). Chitinases. Methods in Enzymology 8, 644-650.

Jones, D., BACON, J. S. D., FARMer, V. C. \& Webley, D. M. (1968). Lysis of cell walls of Mucor ramannianus Möller by a Streptomyces sp. Antonie van Leeuwenhoek 34, 173-182.

Ko, W. \& Lockwood, J. L. (1970). Mechanism of lysis of fungal mycelia in soil. Phytopathology 6o, I48-I54.

Mahadevan, P. R. \& MahadKaR, U. R. (1970). Role of enzymes in growth and morphology of Neurospora crassa: cell-wall-bound enzymes and their possible role in branching. Journal of Bacteriology ror, 94I-947.

Mahadevan, P. R. \& RaO, S. R. (1970). Enzyme degradation of conidial wall during germination of Neurospora crassa. Indian Journal of Experimental Biology 8, 293-297.

Mitchell, R. \& SABAR, N. (I966). Autolytic enzymes in fungal cell walls. Journal of General Microbiology 42, 39-42.

Nelson, N. (1944). A photometric adaptation of the Somogyi method for the determination of glucose. Journal of Biological Chemistry $\mathbf{1 5 3}_{\mathbf{5}}, 375-380$.

Polacheck, Y. \& Rosenberger, R. F. (1975). Autolytic enzymes in hyphae of Aspergillus nidulans: their action on old and newly formed walls. Journal of Bacteriology 121, 332-337.

Reyes, F. \& Byrde, R. J. W. (1973). Partial purification and properties of a $\beta$ - $N$-acetylglucosaminidase from the fungus Sclerotinia fructigena. Biochemical Journal I3I, 38I-388.

Shibata, Y. \& Nisizawa, K. (I965). Microheterogeneity of $\beta$-glucosidases in apricot emulsin. Archives of Biochemistry and Biophysics 109, 516-521.

Skujins, J. J., Potgieter, H. J. \& AleXANDER, M. (I965). Dissolution of fungal cell walls by a streptomycete chitinase and $\beta$-I-3-glucanase. Archives of Biochemistry and Biophysics III, 358-364.

Somogyi, M. (1945). A new reagent for the determination of sugars. Journal of Biological Chemistry 160, $6 I-73$.

Tracey, M. V. (1955). Chitin. In Modern Methods of Plant Analysis, vol, 2, pp. 264-274. Edited by K. Paech and M. V. Tracey. Berlin: Springer-Verlag. 